\title{
DEVELOPMENT AND VALIDATION OF AN ANALYTICAL METHOD FOR QUANTITATIVE DETERMINATION OF BENZENE, TOLUENE, ETHYLBENZENE, XYLENES IN AMBIENT AIR
}

\author{
Le Dinh Vu ${ }^{1, *}$, Phan Tan Lap ${ }^{1}$ and Le Van Tan ${ }^{1}$ \\ ${ }^{1}$ Faculty of Chemical Engineering, Industrial University of Ho Chi Minh City, Go Vap, Ho Chi \\ Minh City-700000, Vietnam \\ *E-mail : ledinhvu@iuh.edu.vn
}

\begin{abstract}
The study describes the qualitative and quantitative analysis of benzene, toluene, ethylbenzene, xylene (BTEX) in the ambient air based on chemical desorption with a less toxic solvent followed by gas-chromatography combined mass-spectroscopy (GC-MS). The analytical procedure was modified OSHA's method in the sampling procedure, the toxic extraction solvent-carbon disulfide $\left(\mathrm{CS}_{2}\right)$ was changed by the less toxic solvent (acetone), subsequent analysis by GC-MS. The parameters and conditions of the method have been optimized. BTEX quantitative concentration ranging from $2.5 \mathrm{ppb}$ to $450 \mathrm{ppb}$ with detection limits were $1.4 \mathrm{ppb}$ (benzene), $1.1 \mathrm{ppb}$ (toluene), 1.0 ppb (ethylbenzene), $0.7 \mathrm{ppb}$ (xylene $(m, p))$ and $1.2 \mathrm{ppb}(\mathrm{xylene}(o))$. At a concentration of $100 \mathrm{ppb}$, the relative standard deviations (RSDs) for BTEX ranged from 3.2\% (benzene) to 7.5\% (xylene $(o)$ ). The new method has also been applied to analyze the real ambient air samples in Ho Chi Minh City. All results indicated that this method can offer a robust, sensitive, and environmentally friendly method for determination of BTEX and other gaseous volatile organic compounds in ambient air.
\end{abstract}

Keywords: BTEX, VOCs, GC-MS, carbon disulfide, acetone, a toxic solvent.

(C) RASĀYAN. All rights reserved

\section{INTRODUCTION}

Benzene, toluene, ethylbenzene and xylenes (BTEX) are volatile organic compounds (VOCs). Their toxicity and ambient air concentrations are regarded as significant air pollutants ${ }^{1-3}$. Ambient air pollutants of BTEX compounds not only play on their independent toxicity but also relate to the secondary pollutants such as peroxyacetylnitrite, ozone, free radicals and nitrogen oxides ${ }^{4-6}$. Human exposure to BTEX can produce many diseases including sperm abnormalities, reduced fetal growth, cardiovascular disease, respiratory dysfunction, asthma ${ }^{7,8}$.

Organic solvents are widely recognized to be of great environmental concern. The reduction of their uses is one of the most important aims of green chemistry ${ }^{9-12}$. Additionally, the appropriate selection of the solvent for an analysis procedure can greatly improve the sustainability of an analysis procedure ${ }^{13,14}$. It is not just an exception for BTEX analysis; a less hazardous waste in analysis procedure, a highly sensitive and accurate method is still a challenge in environmental analytical chemistry.

Current methods for analyzing BTEX in ambient air are EPA analytical method TO-14, Solid-phase micro extraction (SPME) followed by GC-MS or OSHA method No.1005 ${ }^{15-18}$. In these methods, BTEX on activated charcoal is desorbed by thermal or extracted by a chemical with carbon disulfide. The disadvantages of these methods are mandatory, elaborate sampling and advanced instrumentation as double stage thermal desorption (in EPA and SPME-GC/MS methods) or using carbon disulfide which is very hazardous solvent (OSHA method) ${ }^{19,20}$.

In Vietnam, most devices for analyzing BTEX is ordinary gas chromatography, which can only analyze BTEX according to OSHA's method No.1005. The method is quite simple, requiring sampling

Rasayan J. Chem., 11(4), 1537-1543(2018)

http://dx.doi.org/10.31788/RJC.2018.1144061

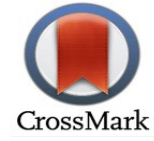


with activated charcoal, chemical desorption BTEX by $1 \mathrm{ml}$ carbon disulfide and subsequent analysis by GC-FID. The disadvantages of this method are high detection limit $(1 \mathrm{ppm})$ and wasting hazardous solvent $\mathrm{CS}_{2}$ in sampling procedure. The detection limit of OSHA's method is higher than Vietnam national technical regulation on ambient air quality that requires ambient air concentration of benzene, toluene, ethylbenzene, xylene $(m, p)$ and xylene $(o)$ are lower than 6,9 ppb, $270 \mathrm{ppb}, 230 \mathrm{ppb}, 230 \mathrm{ppb}$, $230 \mathrm{ppb}$, respectively ${ }^{21}$. So OSHA's method is not adapted for determination of low BTEX concentration in ambient air.

In this present study, the simple sampling requirement with activated charcoal and subsequent chemical desorption as OSHA's method were employed. BTEX in ambient air was absorbed in activated charcoal and was then extracted by acetone instead of carbon disulfide that reduces hazardous waste solvent ${ }^{9,22}$. Additionally, the analytical instrument in the method is gas chromatography combined massspectroscopy, which provides very high sensitivity and accuracy would be ideal for this kind of analysis.

\section{Material and Methods}

\section{EXPERIMENTAL}

Benzene, toluene, ethylbenzene, xylenes, 1,2-dichlorobenzene were purchased from Sigma Aldrich Corporation (St. Louis, MO, USA). All other chemicals were of analytical grade and obtained from Sinopharm Chemical Reagent Co. Ltd (Beijing, China). Charcoal tube No.800B that packed 20/40 mesh coconut shell charcoal is capable of absorbing VOCs including BTEX was purchased from Kitagawa America. Seven centimeters grass tube was filled with charcoal in two sections: (i) section A packed $100 \mathrm{mg}$ charcoal; (ii) section B packed 50mg charcoal. The entrance of charcoal section A is closed with glass wool, another end of section A and both ends of the charcoal section B were closed with a piece of urethane form (Fig.-1).
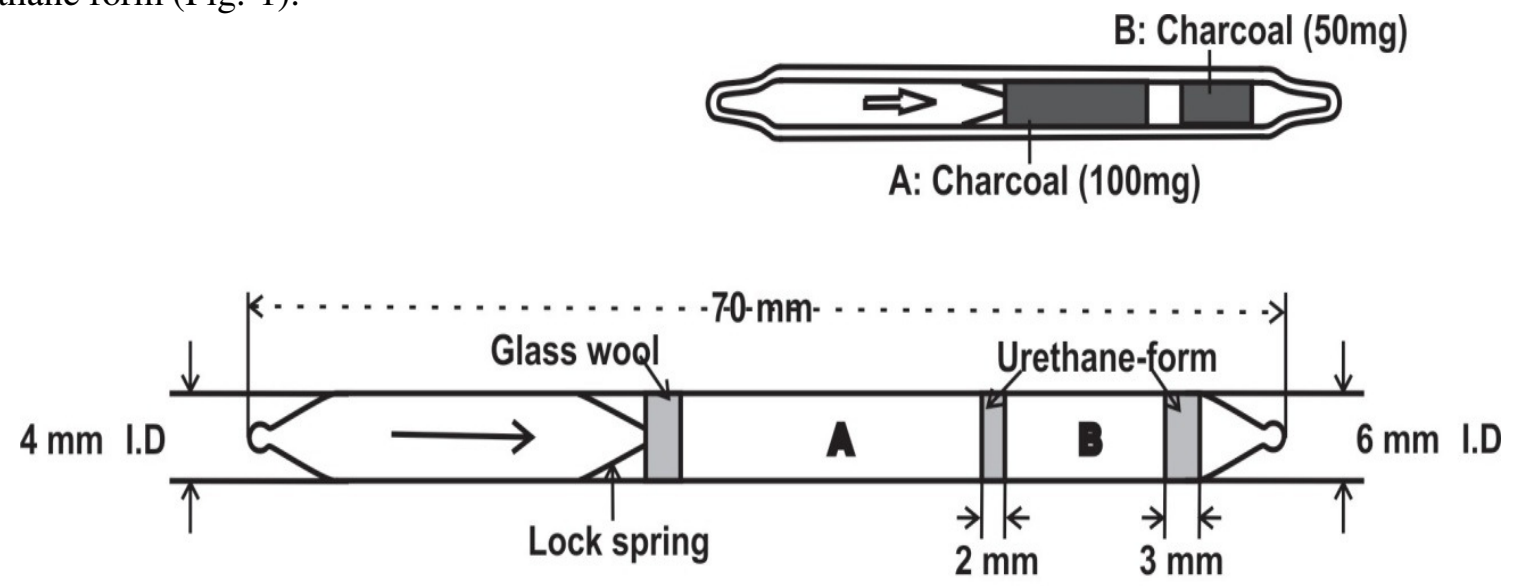

A: $100 \mathrm{mg} \mathrm{20/40} \mathrm{mesh} \mathrm{coconut} \mathrm{shell} \mathrm{charcoal}$

B: $50 \mathrm{mg}$ 20/40 mesh coconut shell charcoal

\section{BTEX Sampling Procedure}

Fig.-1: Charcoal Tube Instruction

BTEX samplers were collected according to OSHA method No.1005, BTEX in ambient air is adsorbed on the charcoal section in passing through the tube (Fig.-2). The sampling amount is to be determined from 0.5 to $1.0 \mathrm{~L}$ by plow meter with the drawing pump (Code 400-00500 HARIO Japan). After collecting BTEX sample, put caps on standard accessory two ends on both tube ends of charcoal tube and storage in a cool, dark place. Desorption of the BTEX vapor is made by $1 \mathrm{~mL}$ solvent $\mathrm{CS}_{2}$ or $1 \mathrm{~mL}$ acetone and subsequent analysis by gas chromatography combined mass spectrometry.

\section{Analytical Instrument Parameters}

Gas chromatography code Agilent 6890, mass detector code Agilent 5973, and nonpolar capillary column code J\&W DB-624 (Agilent, USA) were used. The column length of 30 meters, $0.25 \mathrm{~mm}$ internal 
RASĀYAN J. Chem.

Vol. 11 | No. 4 |1537 - 1543| October - December | 2018

diameter, 1.4 micrometer thick film, the stationary phase has a composition $6 \%$ cyanopropyl phenyl and 94\% polydimethylsiloxane.

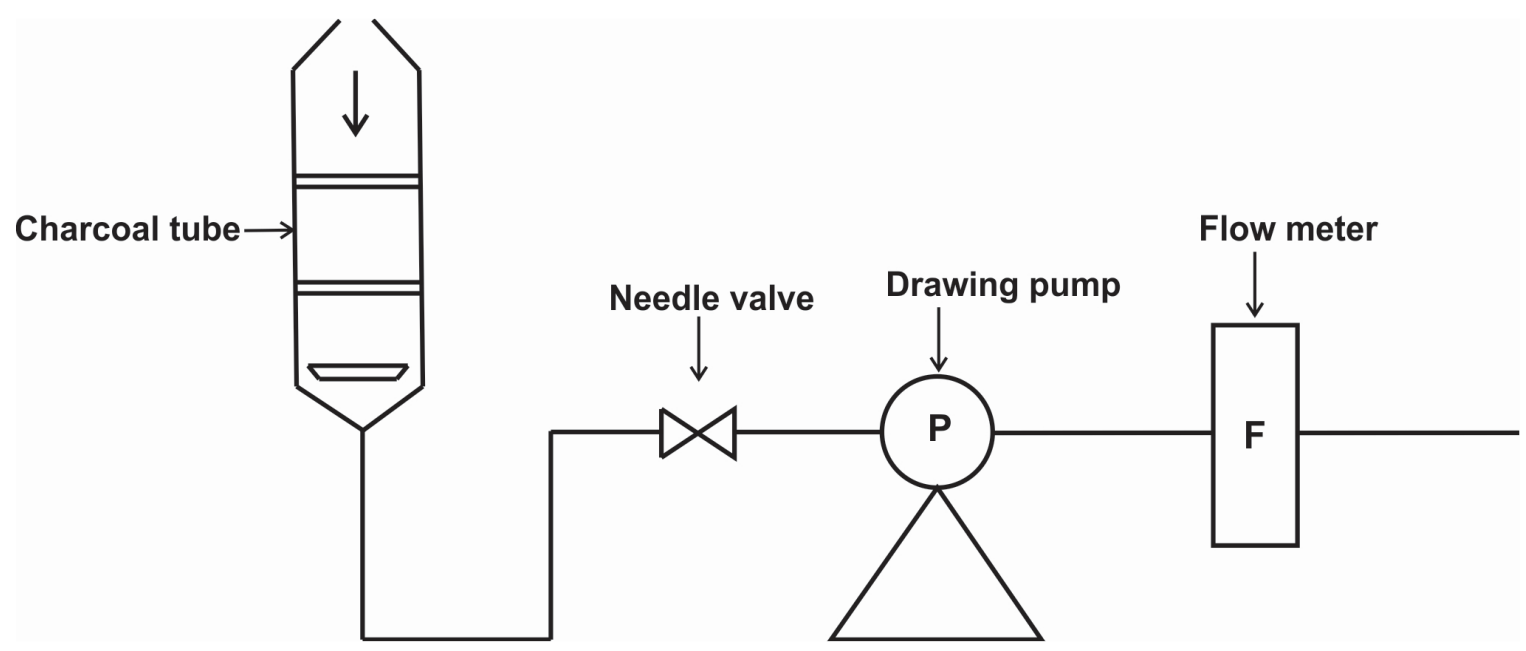

Fig.-2: BTEX Sampling Equipment

Gas chromatography separate conditions as flowing: Capillary column flow of pure He carrier gas was set at $0.9 \mathrm{ml} / \mathrm{min}$; Oven temperature was initially programmed at $60^{\circ} \mathrm{C}$ for 5 minutes, temperature was increased at the rate of $5^{\circ} \mathrm{C} / \mathrm{min}$ to $90^{\circ} \mathrm{C}$ held constant for 2 minutes and then temperature was increased at the rate of $20^{\circ} \mathrm{C} / \mathrm{min}$ to $150^{\circ} \mathrm{C}$ after that held constant for 3 minutes, total running time was 19 minutes. Mass detector (MSD) working with electron impact ionization source (EI), MSD temperature was set at $250^{\circ} \mathrm{C}$. For BTEX qualitative analysis, MSD working in full scan mode with mass scan range was set from $10-400 \mathrm{~m} / \mathrm{z}$ and comparisons with the NIST 14 Mass Spectral Library. For quantitative analysis, MSD working in selective ion monitoring mode (SIM), the target ion fragments were chosen in Table-1.

Table-1: Target Ion Fragments of BTEX in Quantitative Analysis

\begin{tabular}{c|c|c}
\hline Analyte & Specific fragments $(\mathrm{m} / \mathrm{z})$ & Target ions $(\mathrm{m} / \mathrm{z})$ \\
\hline Benzene & $51,63,74,78$ & $63,74,78$ \\
\hline Toluene & $51,65,74,91$ & $65,74,91$ \\
\hline Ethylbenzene & $51,65,77,91,106$ & $77,91,106$ \\
\hline Xylene $(m, p)$ & $51,65,77,91,106$ & $77,91,106$ \\
\hline Xylene $(o)$ & $51,65,77,91,106$ & $77,91,106$ \\
\hline 1,2-dichlorobenzene & $50,75,111,146$ & $75,111,146$ \\
\hline
\end{tabular}

\section{BTEX Quantitative Analysis}

A varies concentrations of BTEX were prepared with the same concentration of internal standard 1,2dichlorobenzen, the calibration line was calculated from ratio of peak area for each analyte to peak area of internal standard with a ratio of their concentration. Concentrations of BTEX in samples were calculated from the calibration lines.

\section{BTEX Desorption Efficiency of Acetone in Sampling Procedure}

\section{RESULTS AND DISCUSSION}

The green approach of the method relies on the reducing hazardous waste by the less toxic solvent. In this method, we modified the sampling procedure of OSHA's method by change extraction solvent carbon disulfide by acetone and evaluating the extraction efficiency (Fig.-3).

Figure-3 shows desorption efficiency of acetone were compared with $\mathrm{CS}_{2}$, the ratio peak area for benzene, toluene, ethyl benzene, xylene $(m, p)$, and xylene $(o)$ were 101,8 \%,97.3\%, 102.4\%, 99.8\% and $96.6 \%$, respectively. The results suggested that BTEX desorption efficiency of acetone is very similar to 
$\mathrm{CS}_{2}$ in the low of BTEX concentration. The results were very consistent with the properties of acetone and $\mathrm{CS}_{2}{ }^{23}$.

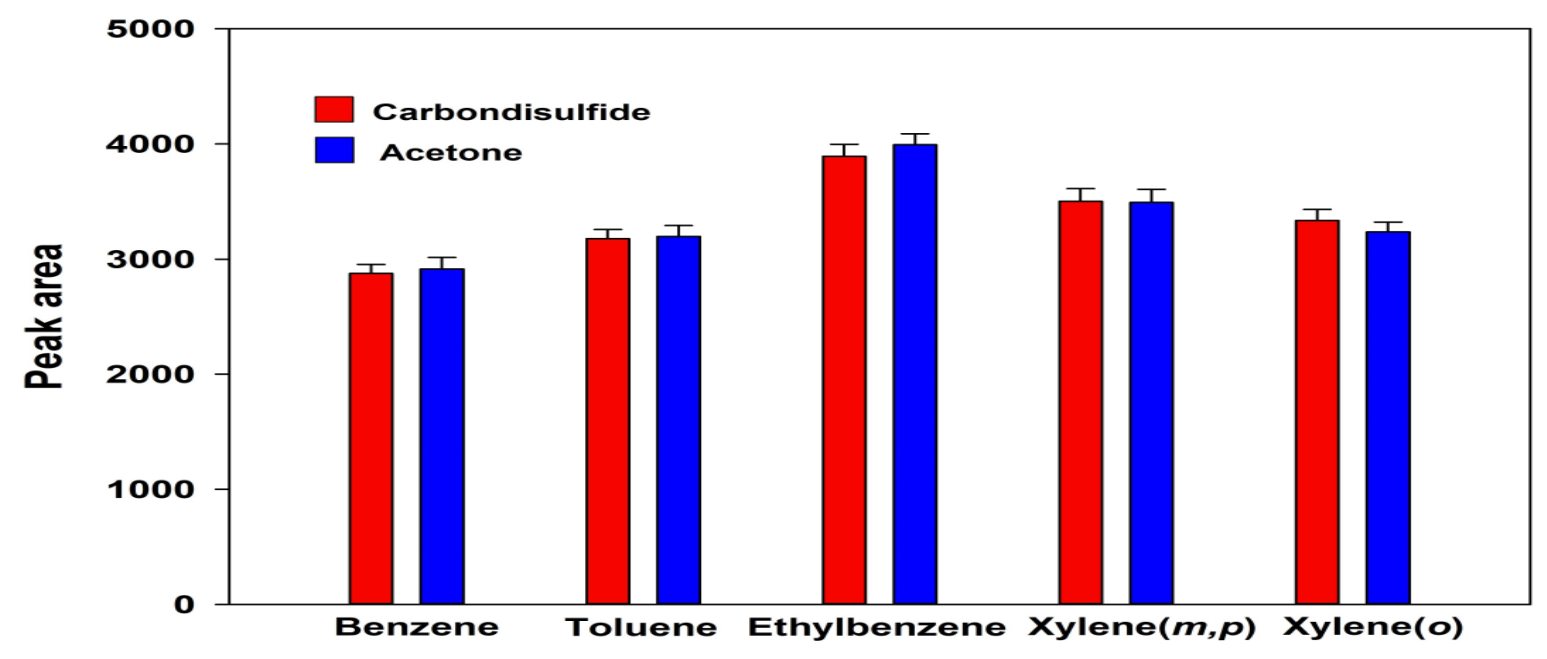

Fig.-3: BTEX Desorption Efficiency of Carbon Disulfide and Acetone. The Concentrations of Benzene, Toluene, Ethylbenzene, Xylene $(o)$, Xylene $(m, p)$ were $100 \mathrm{ppb}$, BTEX absorbed on Charcoal were Diluted by $\mathrm{CS}_{2}(\mathrm{Red})$ or by Acetone (Green). Error Bars are Standard Deviations across Five Repetitive Experiments.

\section{BTEX Quantitative Analysis Method Validation}

Representative chromatography of BTEX with the internal standard is shown in Fig.-4. A dramatic increase in the intensity was observed with the increasing concentrations of BTEX.

A calibration of the ratio of peak area for each analyte to the peak area of internal standard with a ratio of concentration was considered for quantification of BTEX, data regarding retention time, linear range, and correlation coefficient are presented in Table-2. The linear range of benzene, toluene, ethylbenzene, xylenes $(m, p)$ and xylene $(o)$ standards were in the ranges of $4.5-280 \mathrm{ppb}, 3.5-400 \mathrm{ppb}, 2.5-450 \mathrm{ppb}$, $3.5-450 \mathrm{ppb}$ and $3.5-450 \mathrm{ppb}$, respectively. All of the correlation coefficients were higher than 0.995 that confirmed the method can be used for quantitative analysis of BTEX in ambient air.

Additionally, the detection limits of the method were validated, detection limits were calculated from the lowest concentrations of standards that produced peaks (signal) high 3 times more than background peaks (noise), the detection limit of benzene, toluene, ethylbenzene, xylenes $(m, p)$ and xylene $(o)$ were $1.4 \mathrm{ppb}$, $1.1 \mathrm{ppb}, 1.0 \mathrm{ppb}, 0.7 \mathrm{ppb}$, and $1.2 \mathrm{ppb}$, respectively. The detection limit of the present method showed a greatly improved than 1 ppm as target concentration of OSHA's method No 1005.

Table-2: Retention Time, Linear Range of BTEX Quantitative Analytical Method

\begin{tabular}{c|c|c|c|c}
\hline Analyte & Retention time & $\begin{array}{c}\text { Concentration } \\
\text { range }(\mathrm{ppb})\end{array}$ & Regression formula & $\begin{array}{c}\text { Correlation } \\
\text { coefficient }\left(\mathrm{r}^{2}\right)\end{array}$ \\
\hline Benzene & 4.969 & $4.5-280$ & $\mathrm{y}=0.9328 \mathrm{x}+0.0715$ & 0.9950 \\
\hline Toluene & 8.176 & $3.5-400$ & $\mathrm{y}=1.3601 \mathrm{x}+0.0073$ & 0.9997 \\
\hline Ethylbenzene & 11.579 & $2.5-450$ & $\mathrm{y}=1.6495 \mathrm{x}-0.0173$ & 0.9988 \\
\hline Xylene $(m, p)$ & 11.886 & $3.5-450$ & $\mathrm{y}=1.2775 \mathrm{x}-0.0018$ & 0.9994 \\
\hline Xylene $(o)$ & 12.723 & $3.5-450$ & $\mathrm{y}=1.4306 \mathrm{x}-0.0033$ & 0.9992 \\
\hline
\end{tabular}

The precision of method were also obtained at BTEX concentrations were $100 \mathrm{ppb}$, the relative standard deviations (RSDs) were $4.8 \%$ (benzene), 3.2\% (toluene); $6.1 \%$ ethylbenzene, $5.3 \%$ (xylenes $(m, p)$ ) and $7.5 \%$ (xylene $(o)$ ), that shows the method had desirable precision.

Additionally, further experiments for comparison with the standard method on real samples were performed to demonstrate the high accuracy and precision of the method. We used Student's test ( $\left.\mathrm{t}_{\text {test}}\right)$ for mean comparison and Fisher's test $\left(\mathrm{f}_{\text {test }}\right)$ for variances comparison ${ }^{24}$. 
RASĀYAN $J$. Chem.

Vol. 11 | No. 4 | 1537 - 1543| October - December | 2018

As shown in Table-3, all of the statistical values ( $\mathrm{t}_{\text {stat }}$ and $\left.\mathrm{f}_{\text {stat }}\right)$ were less than critical values ( $\mathrm{t}_{\text {crit }}$ of 2.77 and $\mathrm{f}_{\text {crit }}$ of $\left.6.38, \mathrm{n}=5, \mathrm{P}=0.95\right)$. These results demonstrated that the present method is high accuracy and precision for quantitative determination of BTEX in ambient air.

In view of all results, we might conclude that the method held great potential for quantitative assay of BTEX in ambient air with robust sensitivity and reproducibility.

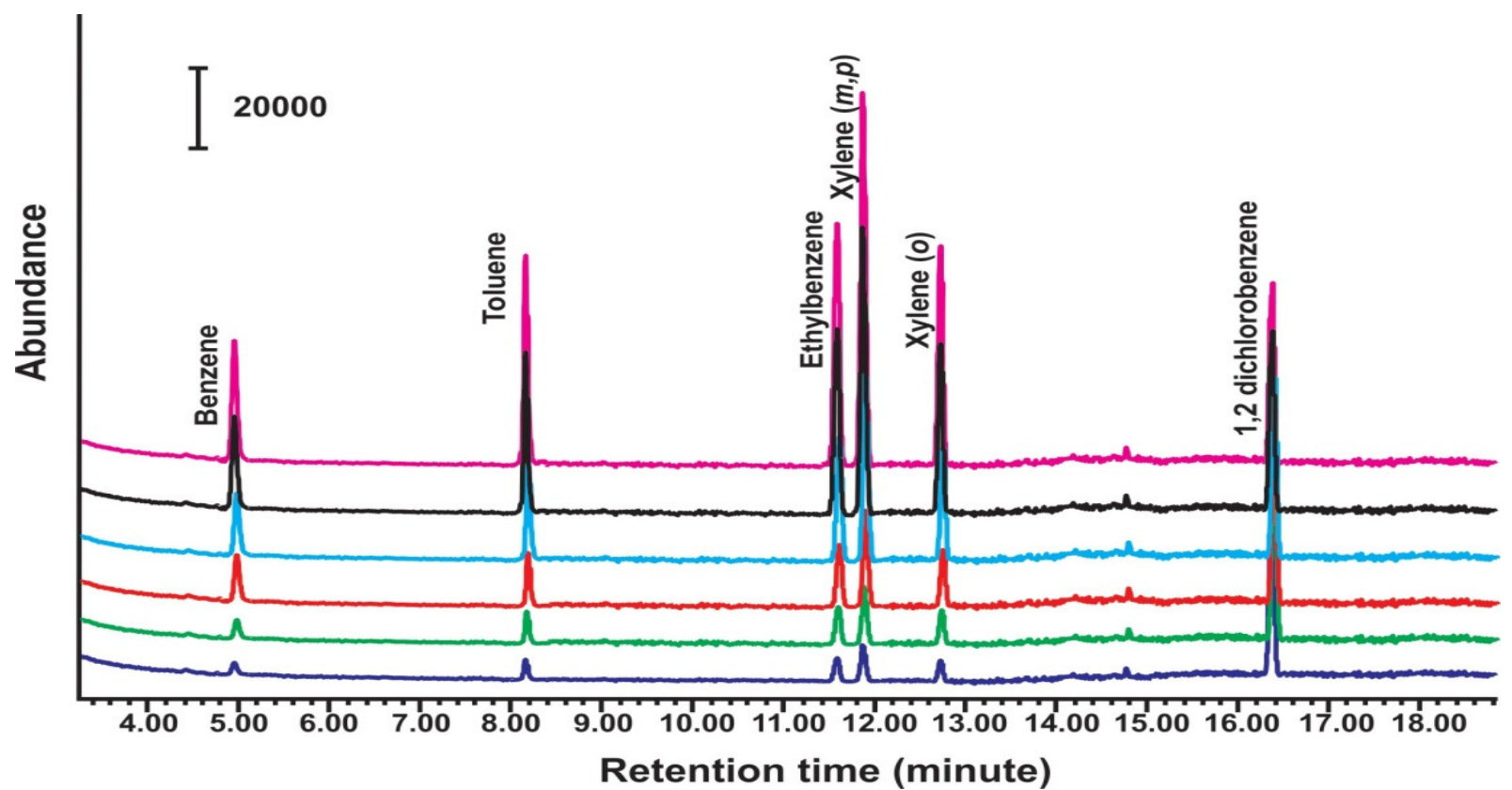

Fig.-4: Intensity Signals responses to BTEX of varying concentrations in the range $5 \mathrm{ppb}-450 \mathrm{ppb}$, Internal Standard Concentration was $250 \mathrm{ppb}$ in All Experiments.

Table-3: Comparison with Standard Method (OSHA Method No.1005) for the Real Samples, the Results was calculated on Five repetitive Experiments, Confident Level of 95\%

\begin{tabular}{l|l|l|l|l|l|l}
\hline Analyte & $\begin{array}{l}\text { Present method } \\
(\text { mean; variance })\end{array}$ & $\begin{array}{l}\text { Standard method } \\
(\text { mean; variance })\end{array}$ & $\mathrm{t}_{\text {stat }}$ & $\mathrm{t}_{\text {crit }}$ & $\mathrm{f}_{\text {stat }}$ & $\mathrm{f}_{\text {crit }}$ \\
\hline Benzene & $49.6 ; 8.03$ & $51.3 ; 5.62$ & 1.01 & 2.13 & 1.43 & 6.38 \\
\hline Toluene & $77.2 ; 7.99$ & $78.7 ; 10.52$ & 2,04 & 2.13 & 1,31 & 6.38 \\
\hline Ethylbenzene & $36.3 ; 3.57$ & $38.4 ; 3.69$ & 1.28 & 2.13 & 1.03 & 6.38 \\
\hline Xylene $(m, p)$ & $46.2 ; 3.24$ & $45.6 ; 2.90$ & 1.66 & 2.13 & 1.12 & 6.38 \\
\hline Xylene $(o)$ & $43.8 ; 3.53$ & $42.1 ; 3.78$ & 1.21 & 2.13 & 1.07 & 6.38 \\
\hline
\end{tabular}

\section{BTEX Quantitative Analysis of Real Samples}

Regarding experiments for application on real samples of the present method, we collected samples at intersections in Ho Chi Minh City at the time of $7 \mathrm{am}, 12 \mathrm{am}$ and $6 \mathrm{pm}$. After extraction of BTEX in charcoal by acetone, BTEX concentrations were measured by GC-MS, and obtained results are shown in Table-4.

Table-4: Concentration of BTEX in Real Samples.

\begin{tabular}{c|c|c|c}
\hline Analyte & Time of sample & $\begin{array}{c}\text { Concentration } \\
(\mathrm{ppb})\end{array}$ & Quality required $(\mathrm{ppb})$ \\
\hline Benzene & $7 \mathrm{am}$ & $31.2-42.4$ & $<6.9$ \\
\hline Benzene & $12 \mathrm{am}$ & $18.0-24.7$ & $<6.9$ \\
\hline Benzene & $6 \mathrm{pm}$ & $49.5-38.3$ & $<6.9$ \\
\hline Toluene & $7 \mathrm{am}$ & $56.7-63.4$ & $<270$ \\
\hline Toluene & $12 \mathrm{am}$ & $34.2-40.8$ & $<270$ \\
\hline Toluene & $6 \mathrm{pm}$ & $56.7-63.4$ & $<270$ \\
\hline Ethylbenzene & $7 \mathrm{am}$ & $24.5-30.4$ & $<230$ \\
\hline
\end{tabular}


RASĀYAN $J$. Chem.

Vol. 11 | No. 4 |1537 - 1543| October - December | 2018

\begin{tabular}{c|c|c|c}
\hline Ethylbenzene & $12 \mathrm{am}$ & $5.1-7.0$ & $<230$ \\
\hline Ethylbenzene & $6 \mathrm{pm}$ & $30.7-39.6$ & $<230$ \\
\hline Xylene $(m, p)$ & $7 \mathrm{am}$ & $39.6-52.0$ & $<230$ \\
\hline Xylene $(m, p)$ & $12 \mathrm{am}$ & $9.8-13.7$ & $<230$ \\
\hline Xylene $(m, p)$ & $6 \mathrm{pm}$ & $40.1-53.0$ & $<230$ \\
\hline Xylene $(o)$ & $7 \mathrm{am}$ & $18.3-28.9$ & $<230$ \\
\hline Xylene $(o)$ & $12 \mathrm{am}$ & $7.3-10.0$ & $<230$ \\
\hline Xylene $(o)$ & $6 \mathrm{pm}$ & $27.8-38.2$ & \\
\hline
\end{tabular}

At the time of 7 am and $6 \mathrm{pm}$, there was very crowded traffic at intersections. Incomplete combustion of BTEX in motor vehicles, especially motorcycles exhaust to ambient air, causes the concentration of BTEX higher than at $12 \mathrm{am}$. In comparison with the requirement from Vietnam national technical regulation for ambient air quality, the concentration of benzene was five times higher than the acceptable value that indicates the ambient air was polluted.

\section{CONCLUSION}

We have developed a novel method for the qualitative and quantitative analysis of benzene, toluene, ethylbenzene, xylenes in ambient air. The green approach of the method based on the change toxic extraction solvent carbon disulfide by acetone in sampling procedure followed analysis by gaschromatography combined mass-spectroscopy. Based on this method, BTEX calibration curves were obtained in a large range and very high correlation coefficient $(>0.995)$ with detection limits were lower than $1.2 \mathrm{ppb}$. The method had desirable precision with relative standard deviations were from $3.2 \%$ (toluene) to $7.5 \%$ (xylene $(o)$ ). Through the application of the method in real samples, we had also found out the concentration of toluene, ethylbenzene and xylene were acceptable but the ambient air was benzene polluted at intersections in Ho Chi Minh City. This study represented the first example of using acetone for chemical desorption BTEX from charcoal in sampling procedure. Compared with conventional BTEX analysis methods, this method is simplified and more environmental friendly. Furthermore, gas-chromatography combined mass-spectroscopy provides a very low detection limit of BTEX. In light of these advantages, the developed BTEX analysis method is expected to provide a high sensitivity, high accuracy and precision, environmentally friendly method for BTEX analysis and related environmental analytical chemistry studies.

\section{ACKNOWLEDGMENT}

The authors would like to thank Industrial University of Ho Chi Minh City for financial support (Contract No. 19/HĐ-ĐHCN, code: 171.4061).

\section{REFERENCES}

1. M. Schiavon, L.M. Martini, C. Corrà, M. Scapinello, G. Coller, P. Tosi, M. Ragazzi, Environ. Pollut., 231(1), 845(2017), DOI: 10.1016/J.Envpol.2017.08.096

2. T.T. Yue, X. Yue, F. Chai, J.N. Hu, Y.T. Lai, L.Q. Hee, R.C. Zhu, Atmos. Environ., 151, 62(2017), DOI: $10.1016 /$ j.atmosenv.2016.12.008

3. H. Amini, V. Hosseini, C. Schindler, H. Hassankhany, M. Yunesian, S.B. Henderson, N. Künzli, Environ. Pollut., 226, 219(2017), DOI: 10.1016/j.envpol.2017.04.027

4. K. Li, W. Wang, M. Ge, J.J. Li, D. Wang, Sci. Rep., 4, 4922(2014), DOI: 10.1038/srep04922

5. M.T. Parsons, I. Sydoryk, A. Lim, T.J. McIntyre, J. Tulip, W. Jäger, K. McDonald, Appl Opt, 50(4), A90(2011), DOI: 10.1364/AO.50.000A90

6. L. Li, H. Li, X.M. Zhang, L. Wang, L.H. Xu, X.Z. Wang, Y.T. Yua, Y.J. Zhang, G. Cao, J. Environ. Sci., 26(1), 214(2014), DOI: 10.1016/S1001-0742(13)60400-3

7. A.L. Bolden, C. F. Kwiatkowski, T. Colborn, Environ. Sci. Technol., 49(9), 5261(2015), DOI: 10.1021/es505316f

8. R. Moolla, C.J. Curtis, J. Knight, Int J Environ Res Public Health, 12(4), 4101(2015), DOI: 10.3390/ijerph120404101

9. T. Welton, Proc. Royal Soc. A, 471, 2183(2015), DOI: 10.1098/rspa.2015.0502 
RASĀYAN J. Chem.

Vol. 11 | No. 4 |1537 - 1543| October - December | 2018

10. A. Gałuszka, Z. Migaszewski, J. Namieśnik, Trends Analyt. Chem., 50,78(2013), DOI: 10.1016/j.trac.2013.04.010

11. S.K. Sharma, A. Chaudhary, R.V. Singh, Rasayan J. Chem., 1(1), 68(2008).

12. G. Pandey, Rasayan J. Chem., 11(3), 942(2018), DOI: 10.31788/RJC.2018.1133031

13. M. Vian, C. Breil, L. Vernes, E. Chaabani, F. Chemat, Curr. Opin. Green Sustainable Chem., 5, 44(2017), DOI: 10.1016/j.cogsc.2017.03.010

14. P.K. Jagtap, K. Tapadia, Rasayan J. Chem., 9(4), 582(2016).

15. United States Environmental Protection Agency, Compendium of Methods for the Determination of Toxic Organic Compounds in Ambient Air, Method TO-14A, Second Edition, 14A-1(1999).

16. N. Baimatova, B. Kenessov, J.A. Koziel, L. Carlsen, M. Bektassov, O.P. Demyanenko, Talanta, 154, 46(2016), DOI: 10.1016/j.talanta.2016.03.050

17. N.Baimatova, J.A. Koziel, B. Kenessov, Anal. Chim. Acta., 873, 38(2015), DOI: 10.1016/j.aca.2015.02.062

18. Occupational Safety and Health Administration, OSHA Analytical Laboratories, OSHA Method 1005, Sampling and Analytical Methods/Benzene, (2001).

19. U.S. Department of Health and Human Services, U.S. Public Health Service, Agency for Toxic Substances and Disease Registry, Toxicological Profile for Carbon Disulfide, (1996).

20. World Health Organization, Concise International Chemical Assessment Document 46, Carbon Disulfide, (2002).

21. Ministry of Natural Resources and Environment of Viet Nam, National technical regulation on ambient air quality, (2009).

22. U.S. Department of Health and Human Services, U.S. Public Health Service, Agency for Toxic Substances and Disease Registry, Toxicological Profile for Acetone, (1994).

23. A.N. Campbell, E.M. Kartzmark , S.C. Anand, Can. J. Chem., 49(13), 2183(1971), DOI: 10.1139/v71-357

24. K.R. Lung, M.A. Gorko, J. Llewelyn, N. Wiggins, J. Autom. Methods Manag. Chem., 25(6), 123(2003), DOI: $10.1155 / \mathrm{S} 146392460300021 \mathrm{X}$

[RJC-4061/2018] 